\title{
STUDIES ON LEPROSY
}

\section{PART 1. STUDIES ON VITAL PHYSIOLOGY OF LEPROSY \\ I SKIN TEMPERATURE}

2) The Change of Skin Temperature Caused by Autonomic Nervous T'oxins

\section{HIDEYA KATSUMI}

(Dept. of Dermatology, Niigata University Medical School)

(Director: Prof. H. Tanaka)

Subcutaneous injection of $0.1 \%$ Adrenalin, $0.1 \%$ atropin and $1.0 \%$ pilocarpin $(1 \mathrm{cc}$ in the male and $0.7 \mathrm{cc}$ in the female) was carried out in 9 cases of lepromatous, 3 of macular, 1 of nervous and 4 of non leprosy patients undifferentiated from leprosy. Over 90 minutes after the injection the temperature in the forehead, in the lesion of the forearms and legs, in the buccal cavity and the function of autonomic nervous system were examined and compared with those of the normal people.

'T he difference is more remarkable in the lepromatous than the macular and in serious old cases than in the slight cases. In severe cases there exists no paralleled relation between the change of skin lesion and the functions of autonomic nerves.

'This change is produced by the disturbance of peripheral sensory nerves and persistently recognized after the skin cruptions have been clinically disappeared.

The measurenent of skin tempcrature enables to some degree to differentiate non-leprosy patients who has sensory disturbances from leprosy.

\section{癩 の 研 觉}

\section{第 1 篇 瀬の生体生理学的研究 \\ 第 1 皮 膚 温 度 (その2) \\ 自律神経毒による皮温の変動}

\author{
新潟大学医学部皮涌科䁇尿器科教室 \\ （皮覤科主任 田 中 宏教授） \\ 助手勝見秀也
}

（昭和 30 年 4. 月 14 日受稿）

\footnotetext{
諸言

その 1 に於て温熱的刺载による瀨患者前額部皮温变動

は健常人のそれと異なるととを述べそれが体温調節作

用と重要な関係あるととについて述べた。然らば体温調
}

節に関しては古来より最も関係めるは自律神経系なりと せられて居り，癩の主症状なる汗分泌障碍及び知党麻痺 も自律神経との関係が重要であるので, 自律神経毒に対 する瀨患者皮温変動を中心とし, 自律神経機能との関係 について健常人のそれと比較検討して見た。 


\section{文献的考察}

I）アドレナリン

Langley, Lewy-Wechsclman, Meyen-Gottlieb, Hess, Brieger, Haschimoto ${ }^{1)}$, Fischer, Landolff, 永山 ${ }^{2)}$ 等は ドレナリンの作用により皮成血管の収縮を見, 小坂, 田 坂 $^{3}$, 橋本 ${ }^{4}$ 等は皮膚温度の低下を証明した。岸方は千 倍アドレナリンを当体重的 $0.3 \mathrm{cc}$ を皮下注射し, 皮温は 一旦下降し, 次で旧に戾るか或はか穴つて一時上昇する と述べて居るが，それらは用量の如何, 注射方法, 外囲 状況, 部位, 個体による感受性によつて相当異なると考 えられるが，種々の条件を一定にして行なえば，個体に よるアドレナリン感受性が大きな要因となり，その場合 に於ける血圧, 脈搏数, 心悸克進と皮温との関倸が重要 となるが，未だそれ等の関係についての詳細な報告はな。 い。

アドレナリンの動物殊に家鬼体温に攵ばす影響につい ては今日までの報告は必ずしも一致せず, 多くの学者, Eppinger $\cdot$ Falta $\cdot$ Rudinger ${ }^{6}$, Juschtschenko ${ }^{7}$, Freund - $\mathrm{Grafe}^{8)}$, Haschimoto ${ }^{1)}$, 佐伯 ${ }^{9}$, 岸 ${ }^{5)}$, 等は家鬼に一定 量（玨当0.5〜1.0退）のアドレナリンを皮下注射すれば 殆んど常に体温の上昇することを報告しているが，Rie$\operatorname{ser}^{10)}$ はとれを否定し，体温のかえつて下降するととを 報告す。又体温の下降するととは Oliver ・ Schäfer ${ }^{11}{ }^{11}$, Tarmasio, Pöhl, Wolownik, Abderhalden • Slavu 等に よりても亦報告されて居る。少 Bauer ${ }^{12)}$ ，は人について 34例中，22例に上昇を，12例に下降を認めて居る。アド レナリンの皮下注射による体温の变化については上昇,

下降々両様の報告があるが，その機転に関し内田 ${ }^{13)}$ ，川 島 $^{14)}$ ，土田 ${ }^{13)}$ は体温を上昇せしむるは主に体温調節中 枢の温中枢を刺蛓興隹する事によつて起り，末梢性の体 温上昇作用は極めて微力であると述べ，体温を下降せし むるは副交感神経系に属する狄義の体温調節中悩の刺战 興奮せらるる為で老るとして居る。

II) ピロカルピン

Loewey・Wechselmann はピロカルピン注射により皮 首应管は抎張すると述べ, 田报 ${ }^{3)}$ は本剂注射後, 体内温 度の降下と共に熱幅射及び体表面温度は減少せずして寧 ろ增加するが，基礎代謝の減退する時期に全れば体内温 に平行して皮温も下降すると, 橋本” は皮温は初め上昇 するも後下降すると, 岸可は下降率少なく, 時には却つ て軽度の上昇を見ると述べ，上記報告者け大体卜降万当 は初期. 1 昇し後卜降すると述べて居る。

体温については Monat・Doyon・ Taenesen，熙沢 ${ }^{(6)}$,
陳 ${ }^{17)}$, 岸5 等はピロカルピン注射により家鬼の体温下降 を, 吉永 ${ }^{18)}$ は甘日鼠にて, Döblin は臨牀的亚びに実験 的に体温の下降を報告している。前述の如くピロカルピ ンは体温を下降せしむるが，其の下降機転は，黑沢 ${ }^{16)}$, 陳 ${ }^{17)}$ 等化よつて迷走神経の中枢部に存在するという冷 中怄の刺战興舊によるものと結論されて居る。

III）アトロピン

分必神経の末端に作用し，諸腺殊に汗腺の分珌機能を 抑制するものである事は一般に認められて居る。Meyer ・Gotlieb 等によれば少量注射初期化岁つては血管運動 中怄を刺戟し皮筩血管の収縮を来たさしめるが，大量注 射乃至注射末期にめつては却つて之を麻浡し皮盾血管を 㹡張すると述べ，Schilf は本郕は皮店应管を抎張すると 云い, 永山地は $1.0 \%$ 硫酸アトロピン液 $0.5 \sim 1.0 \mathrm{cc}$ を 中等大の家臣に注射すれば不感蒸発の減少久び耳殸直管 の収縮を起すので皮温は下降するものと推論したが，人 体実験にては却つて皮温の上昇を認めて居る。

\section{実験方法}

殆んどその 1 に述べたと同様であるが，ただ使用計器は D 3 型 $\mathrm{E}$ 級の他に，D 3 型 $\mathrm{A}$ 級感度 $2.9 \times 10^{-10} \mathrm{~A} ， 4.45$ $x^{-6} \mathrm{~V}$ ，の両者を同時に用いた。

测定部は前額部のほか前脂又は下腿の病策部をも同時 に行つた゚

実験例 結節霣 9 例, 斑紋獺 8 例, 神経瀨 1 例, 顆と 鑑別困難な非䫝患者 4 例で岂る。

注射薬剂は $0.1 \%$ ア ケドレナリン，0.1\%アトロピン， $1.0 \%$ ピロカルピンで皮下注射とし, 注射量は男 $1.0 \mathrm{cc}$, 女 $0.7 \mathrm{cc}$ とした。

実験は気温約 $20^{\circ} \mathrm{C}$, 湿度約 $60 \%$ ，無風の腤室で行い， 被験者を少くとも30分以上仰卧, 安静にし, 測定部位の 皮温の一定するのをまつて薬片の注射を行い, 最初の 10 分間は $1 \sim 2$ 分間隔， 20 分までは 2 分間隔，60分までは 5 分, その後は 10 分間隔で計 35 回測定し, 90 分後まで追 及した。自律神経機能及び口腔内温度は最初 10 分間は 5 分, その後 1 時間までは 10 分, その後は 30 分間隔に施行 した。

\section{実 験成 績}
A）健㡽人及び顆患者
I） アドレナリン
a) 前額部皮面温 $(1 \sim 4$ 図 $)$

徤常人では注射直後上り降下し始めるか义は一時的に

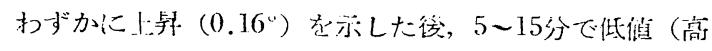
低差 $0.61^{\circ}$ ) に達し，その後 40 分位まで潄次上昇, 以後 
60分位まで下降 $\left(0.83^{\circ}\right)$ し，以後旧にかえる。斑紋癩 では注射後の下降は 5 20 分位で低值（高低差 $0.44^{\circ}$ ) を示し，以後健常人に似た曲線を示す。結節霜では注射 直後よりかえつて上昇 $\left(1.45^{\circ}\right)$ する例，非常に不規則 な動摇を示す例，1時間位すで漸次下降し，以後上昇旧 に復す例（高低差 $1.25^{\circ}$ ) などが見られた。

b) 前膊発疹部皮温 $(1 \sim 4$ 脳 $)$

健常人対称部では直後より下降を絖けるもの $\left(4.38^{\circ}\right)$ と，5分位まで急激に下降 $\left(1.91^{\circ}\right)$ し，再び上昇 $(3.30$ ○)する例と女るが，後者の如き例はアドレナリンに過 敏にして血圧, 脈膊数の变動及び自覚的に心悸圥進を強 く訴えた。斑紋瀨では健常人に似た曲線を示したが，最 初の下降の発現は健常人より垤く5〜20分で現われ，下゙ 降度 $\left(1.22^{\circ}\right)$ も少ない。

結節瀨では注射後急激に上昇し，20３0 分にて最高

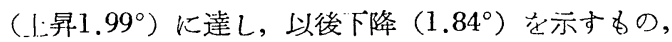
非常に不規則な例，下降を絖けて行く例（下降度 $1.68^{\circ}$ ) などが見られた。

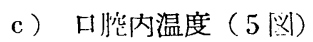

健常人では大体 5 分位、でト降 $\left(0.07^{\circ} \mathrm{C}\right)$ L，以後漸次 L.景し再び60分位で下降するが，斑紋䙡でる20分位で最 低值 $\left(0.30^{\circ}\right)$ を示し，下降久び上昇度は健常人よりも 大でめる。結節癩では10分位にて最も下降して，後上昇 し, 動摇減傾は $0.45^{\circ} \mathrm{C}$ で最大である。

d）血压，脈膊数，心悸圥進と皮温との関係（1 4濦)

健唐人では注射直後血圧上昇により皮温は低下し，脈
膊数増加, 心悸䒕進めらわれ, 後 5 分位で皮温の上昇を 示した。斑紋嚓では前額部は殆んど健常人と同様ですつ たが，皮㾸部に於ては血圧上昇に依る皮温低下，脈膊数 増加, 心悸艺進後の皮温.上昇は健带人より遅れて10分位 後に現われ，反応度即ち上昇下降の程度与健常人に比し て.軽度であつた。

結節顆では全く不規則で一定の傾向は示さず血圧の」: 昇に対して却つて皮温は漸次上昇を絖けるなど種々雑多 であつた。

特にかかる傾向は患部に於て著明に劲められた。

小括

先人の報告並びに余の実験成績よりして，健康人では 皮温は一旦下降し次いで旧に復するか，或は反対に一時 上笔し後下降するものと考えられ，それが機序として初 期皮温下降はアドレナリンによる末梢毛細血管の収縮, ついで血圧下降, 脈膊数の増加による毛細血管抎張と流 量の増加が考えられる。又アドレナリン過敏例に扣ける 而一週性_L昇は町田 $\left.{ }^{19}\right)$ によれば四肢立管に於けるアドレ ナリンの作用は，血压上昇と闹時に皮筑血管の抎張が見 られるといらが，それは四肢血管の自動的拡大によるの ではなくて，血圧の上型により念激に増加した流血量の 増大と, 更により主要な因子として脈搏数の念速な増加 によると考えた方が妥当のようである。的し勿論個体に よる感受性によつても相当に異なつて来るといら事が考 えられる。斑紋癩に扎いては皮瘆の存在しない前額部で は健常人の如き関係を示すが，斑綿の存在する前膊では
第 1 図
健唐人アドレナリン注射
B. D. ……血 圧
P. Z. …...脈搏数
A. Z.……呼吸数
S. ……前額部皮温
H. ……前膊部皮温

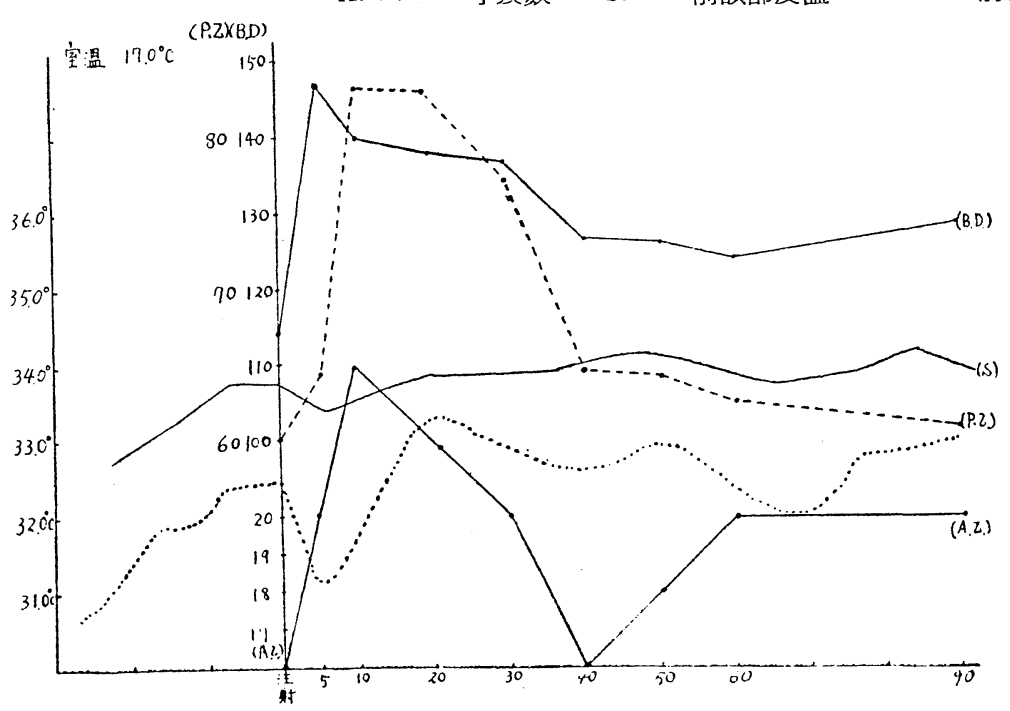




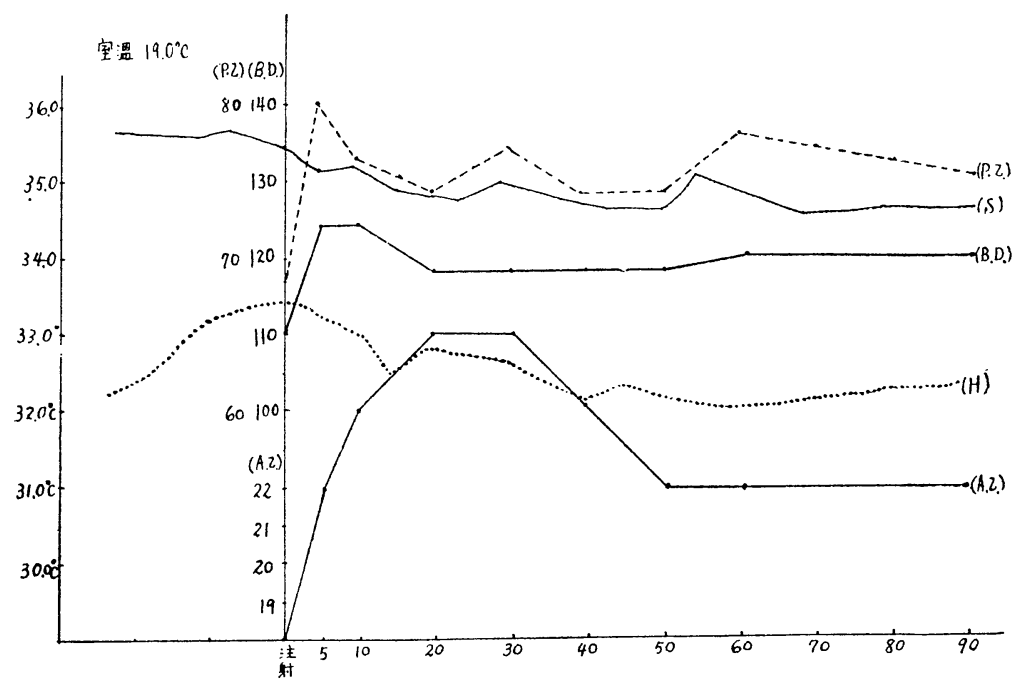

第 3 図

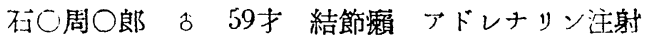

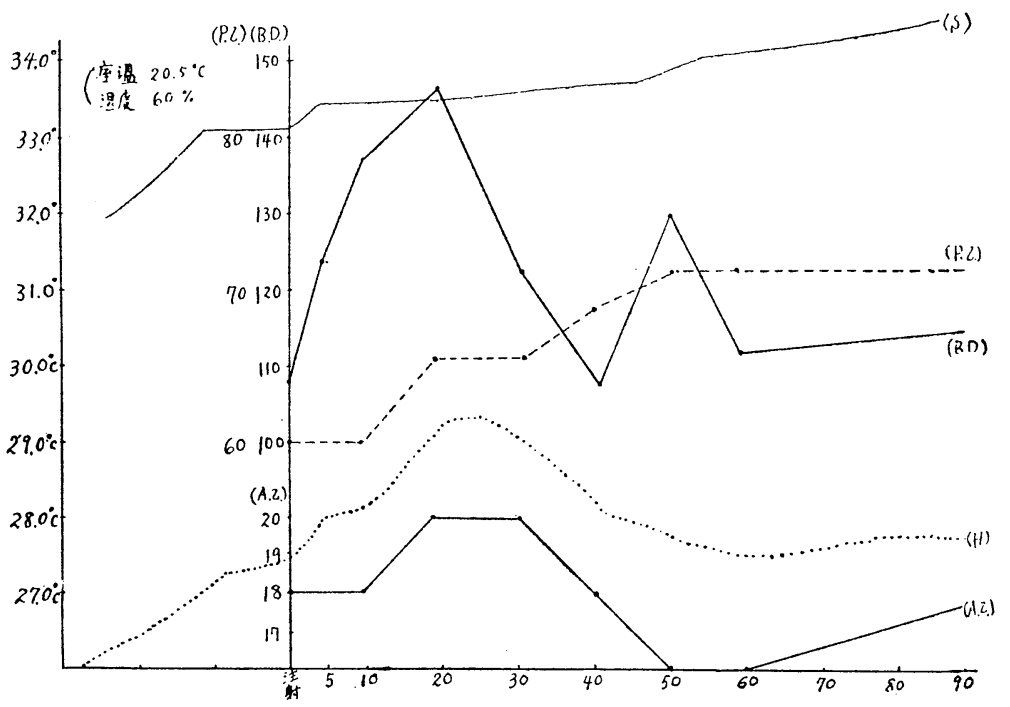


第 4 図

川○徳○郎 今 結節瀨 アドレナリン注射

室温 $17.5^{\circ} \mathrm{C} \sim 18.0^{\circ} \mathrm{C}$, 湿度 $58 \%$

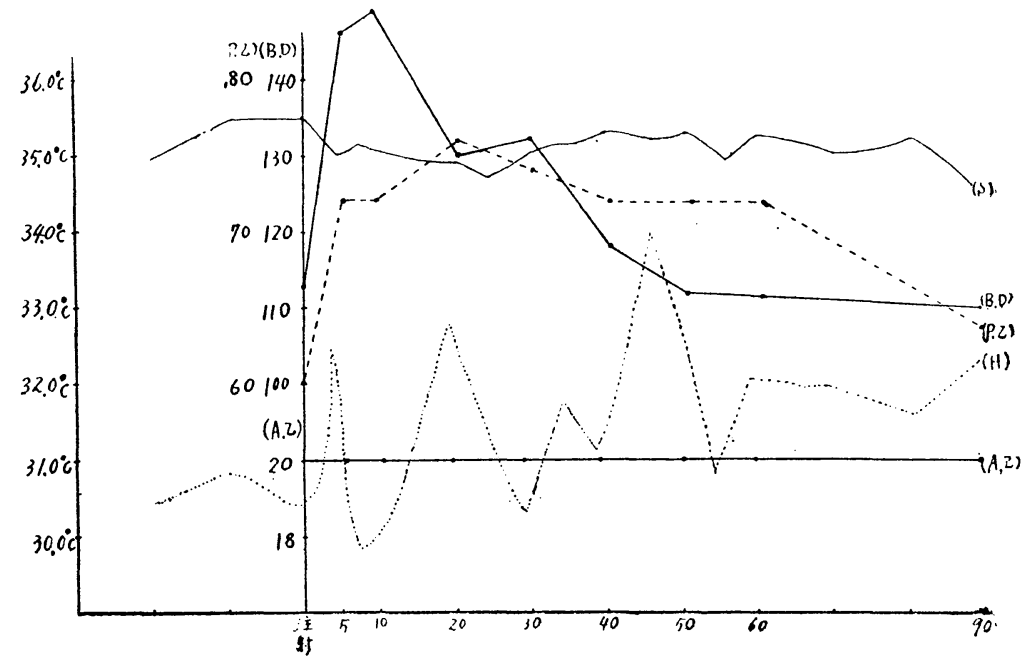

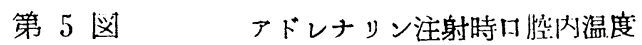

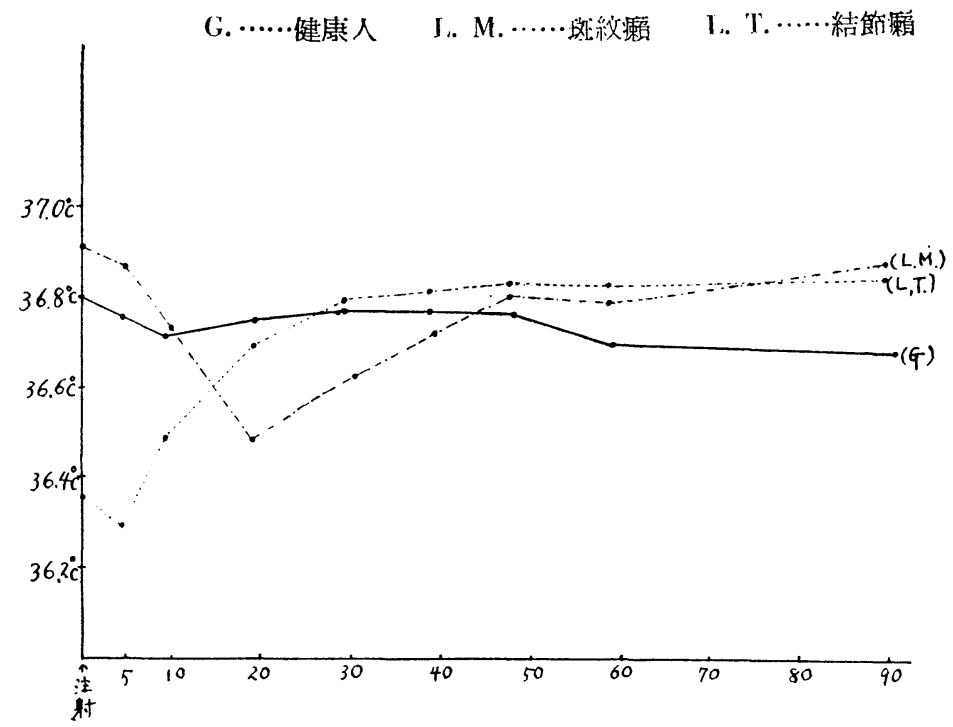


健常人よりその反心程度が弱い。結節瀨は前額部並びに 皮疹部に拁いても不規則大動摇を示し，殊に皮疹部には それが著明でせり，前額部においては軽度でもり，前額 部における軽度の不規則な動摇を示すのは，結節攋にお ける皮疹発現頻度か㘖面に最多であると云ら事を考える ならば，外見上健常と見えても瀨性変化の存在を否定す る事が出来ないと考えられる。体温の変動から検討すれ げ，健常人及び癩患者共程度の差とそ卷れ，一旦下降し 再び上昇する過程は同様でめり，とれをもつて内田 ${ }^{13)}$, 川島 ${ }^{14)}$ ，土田 ${ }^{15)}$ の体温下降機序より中枢部の障得を除 去する事は出来ないが，皮温を自律神経機能との平衡関 係の消失より考えるならば, 瀨に於ける皮温変動の異常 は主に自律神経末梢部の障碍によると考えられる。

II) ピロカルピン

a) 前額部皮面温 $(6 \sim 10 \mid$ 约 $)$

健常人では直後軽度の」昇 $\left(0.2^{\circ}\right)$ 遂来し, 約 7 分で 最高に達し，次いで比較的急激に降トし，30分で最低值 (高低差 $2.11^{\circ} \mathrm{C}$ ) を示し，之より漸次上昇旧に復す。斑 緅瀨では直後上昇の発現時間が幄れ, 約10分にて最高值 も示し, 漸次降下する。降下度は $2.43^{\circ} \mathrm{C}$ て健常人より 大で岕る。結節瀨は上昇時間は約 15 分にて最高偭を示

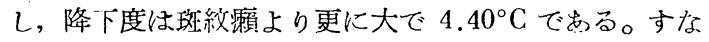
わち最高反忘值を示す所は時間的に斑䋇, 結節瀨と順心 暒れ，かつ反心度が著明となる。

b) 発疹部皮面温 ( 6 〜 10依)

健常人対称部では約 7 分迄上昇 $\left(0.39^{\circ} \mathrm{C}\right)$ を来し以後 急激な降下を来たし, 降下度は $5.76^{\circ} \mathrm{C}$ で後二者に比し て遥かに大で岁つた。斑紋霜は最高上昇 $\left(1.19^{\circ}\right)$ は約 25 分以見られ，上昇度は健常人より大であるが，降下度は $2.59^{\circ} \mathrm{C}$ で健常人に比し遥かに少ない。又始めより上开 をつつけ60分位にて最高となり, 以後下降する例も見ら れた。結節瀬は初期上昇の時間は遅く，20〜40分汽つつ き，上昇度は $1.73^{\circ} \mathrm{C}$ で最も大きく，以後の下降度も $1.83^{\circ} \mathrm{C}$ で非常に少なく, 又殆んでト降を示さない例, 却つて上昇を示す例子見られた。

c）口腙内温度 (11怄)

健常人及び斑紋攧では漸次下降し上昇は認められな い。而し斑紋㸃頁の下降度は $0.76^{\circ} \mathrm{C}$ て健唐者 $\left(0.38^{\circ}\right)$ よ りも大である。結節では30分位にて最も下降し, 以後漸 次上舁する。又下降度は前二者に比し遥かに大にして $0.76^{\circ} \mathrm{C}$ でせつた。

d) 自律神経機能と皮温との関係 $(6 \sim 10$ 汹)

健常人では脈搏数増加と共に皮温も_L昇な示し，5〜 10分で脈搏数が減少し, 発汗か現われる様になると急激 にト降するが；玟約癩では脈搏数増加するも皮温の上昇 は健常人より大分遅れて見られる。結節癩に於ても同様 であるが初期脈搏数増加に拘らず皮温は却つて下降を示 す例も歹，又患部に於ては健常人対称部は相当皮温の 下降を示すに拘らず結節瀨では却つて皮温の上昇を示す 例さえ見られた。

向ピロカルピンに於ては発计と皮温との関係か特に重 要でするすので，同一条件下に生体抵抗哭を用いても測定 した。それによると前額部に於ては瀨患者と健常とは殆 んど同程度か多少とも䞄患者に発汗が多い事が分つた。 而し患部に於ては瀨患者の方が発汗の発現毣く且つ遥か に少ない。乙れ等の事実から発汗が現われる直後からの 皮温の下降は発汗による為でむると考えられる。

第 6 畄健康人 ピロカルピン注射（室温 $18^{\circ} \mathrm{C}$, 湿度 $68 \%$ )

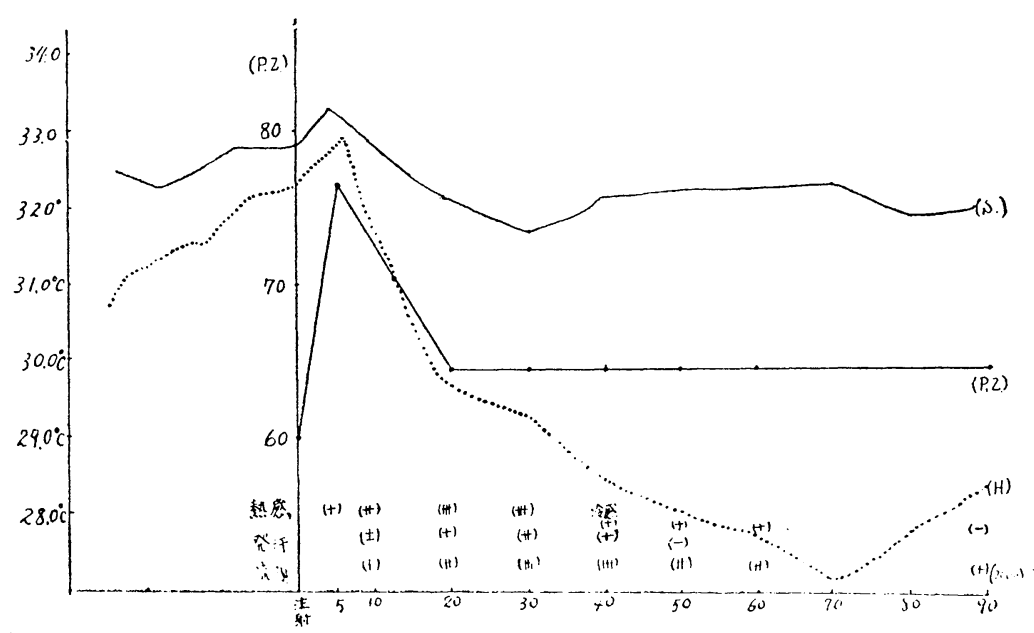


第 7 図

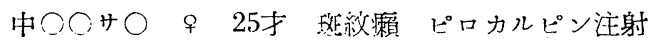

(室温 $20^{\circ} \mathrm{C}$, 湿度 64\%)

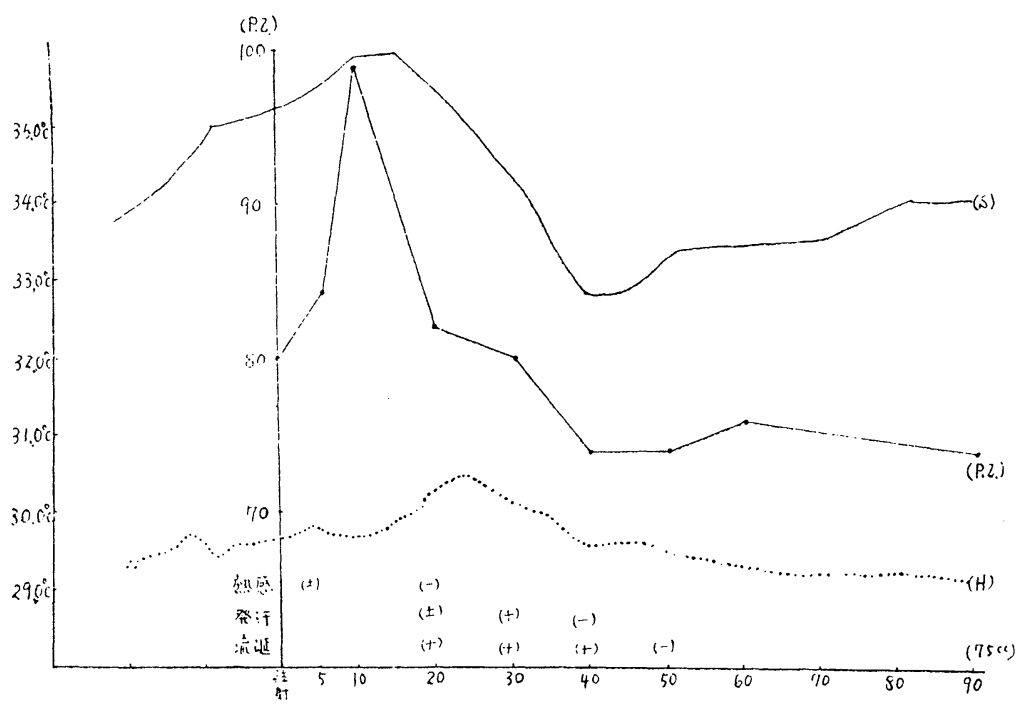

解 8 図

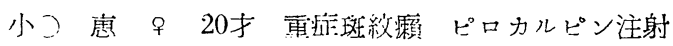
（室温 $21^{\circ} \mathrm{C}$, 湿度 59\%另)

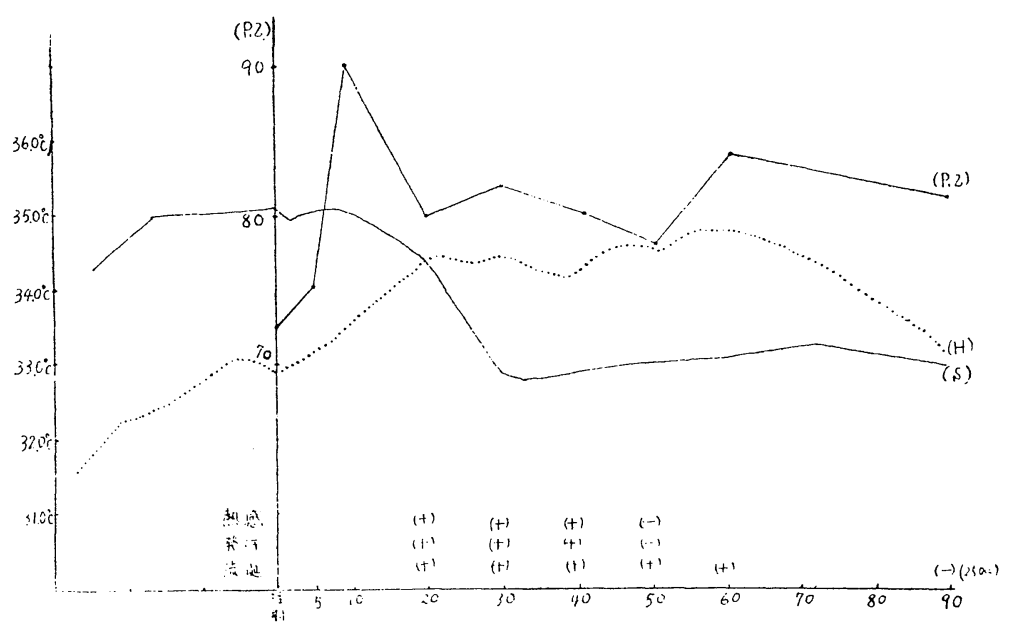


第 9 図

宮○ク○９４5才 結節顆 ピロカルピン注射

(室温 $18.0^{\circ} \mathrm{C}$, 湿度 $70 \%$ )

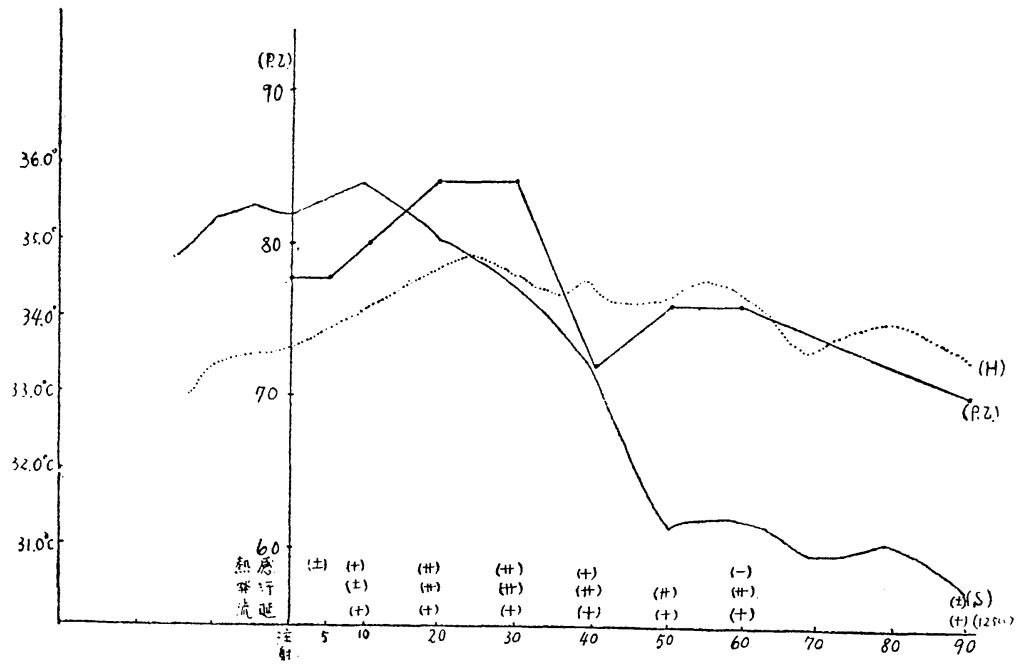

第 10 図

中○清 054 才 結節攋 ピロカルピン注射

(室温. $21.0^{\circ} \mathrm{C}$ ，湿度 $58 \%$ )

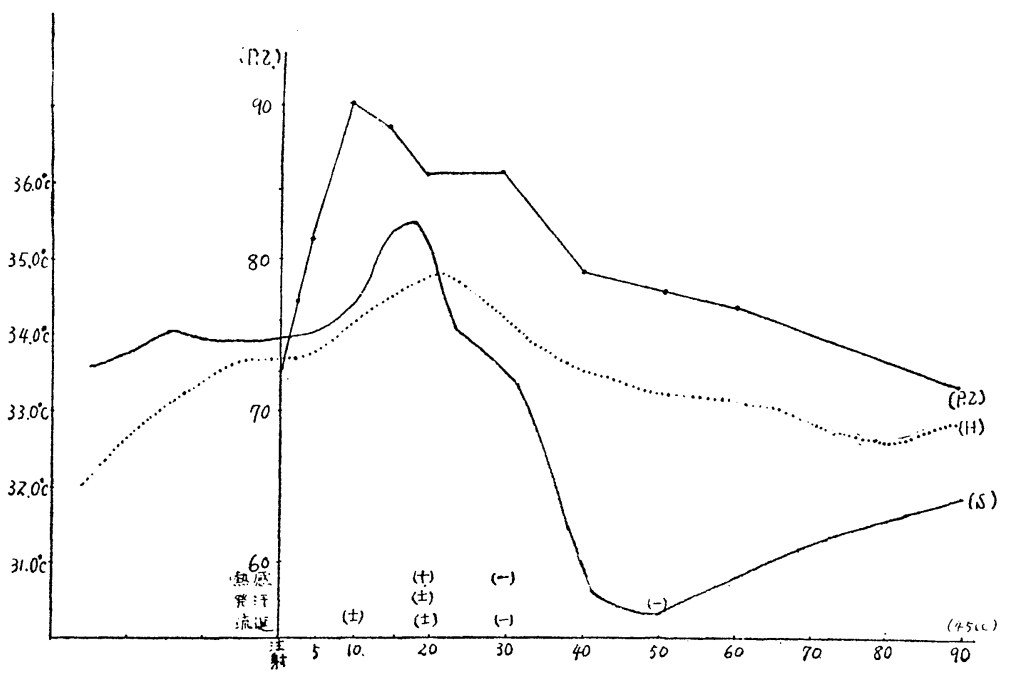


第 11 图 ピロカルピン注射時け際入温度
G. ……健康人
L. M. ……㴂紋獺
L. I. …...結節獺

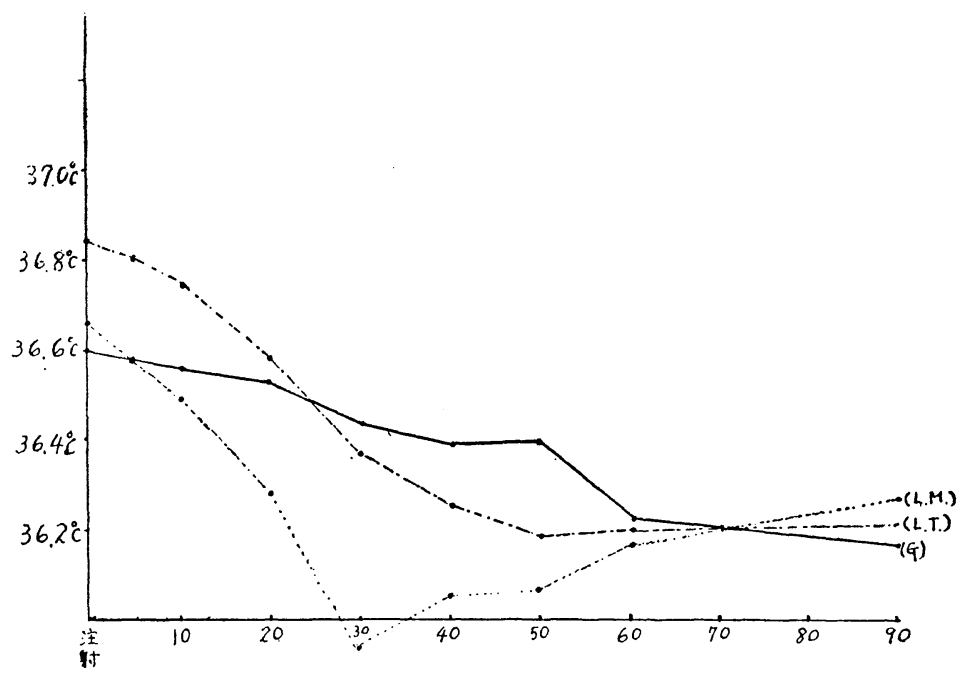

小括

ピロカルピン注射による皮温の変動は健常人に於ては 注射後約 7 分位末では脈搏数が増加と共にわずかに上昇 し以後下降を示すが，上昇はピロカルピンによる皮触血 管の拡張と脈搏数増加による流血量の増加が主因である と考えられ，その後の下降は発汗による為で㣽る。攋患 者心於ては健常人に比して脈搏数の増加の点では個人的 差違による以外变化は認められないが，皮温の上昇が健 常人に比して逑れて現われる。特に結節瀨に於ては斑紋 瀨より，又患部に於ては前額部より迤れて現われる事実， および発疹部皮面温の.上昇が高值を示すのは発汗による 下降か起らず，ただ皮闻血管の拡張による皮温上昇が持 続する為と考えられる事, さらに患部に限局性の発汗障 碍など考え合せて副交感神経の未梢の障碍によるものと 考えられる。

\section{III）アトロピン}

健康人, 癩患者いずれの場合に於ても一定の傾向は見 られず概して緩慢な経過を示した。

又自律神経機能との関係も著明なものは見られなかつ た。

B）癩と鑑別困難であつた韭癩患者

a ）下腿部に知覚障碍の認められた症例

ピロカルピン注射により前額部及び知覚障碍部共に緩 慢な曲線で衤とは全く異つた曲線を示したが，アドレナ リンに対しては賲との相異け殆んどみられなかつた。 b）右足踪に難治の無痛性潰瘍の存在していた症例 ピロカルピソで健常人に似た曲線を示した。

c）皮温と自律神経機能との関係

アドレナリンに於ては健常人の如く血圧上昇により前 額部及び足関節部の皮温下降が見られ，血圧下降，脈搏 数の增加によつて皮温の上昇を認めた。ピロカルピンに 於ても健常者と全く同様か，出るいはそれに近い反応を 示した。

C）治療後の実験成綪

TBI 治療後約 1 年前, 実験施行例中の治瘾症例で, 結 節，玟紋の消失した10例に就て治瘾前と同一条件で皮温 を測定した結果は，皮温の経過には大多数の例に於て著 明な变化は見られず唯発病後 6 ケ月の治療で皮疹の完 全に消失した結節瀨の 1 例のみは健度人と同様の曲線を 示した。合本症は皮疹部の組織学的検查に颃いても軽度 な角質肥厚を認めるのみで瀬病変は全く認められなくな つて居た。

\section{総括}

アドレナリンに対しては斑絔瀨及び結節癩共健常者と 異なつた時間的推移を示したが，斑紋瀨に於ては著明で はなく，とくに前額部では殆んど健常者と変らず，患部 に於ても皮温下降の時間の遲延及び下降度に僅かの差異 を認めるのみであり，自律神経機能との関係に於ても闰

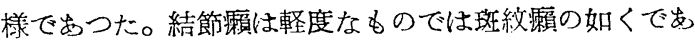
るが，重症陳旧例では皮温変化が非常に不規則となり自 


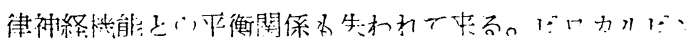

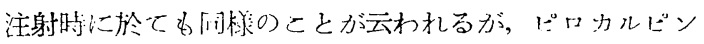
の場合の变化は一段之著明で, 玟級瀨に於ても重病例で は健常人に比して顕著なる相湋が見られた。们しとれ等: は発汗による变動が主要因をなすものですり，発汗以後 の变化の相違は当然起りらるものと考えられる。非瀨患 者はピロカルピン注射の場合には健常人及び攋患者と異 つた皮温の変動を示したが，これ等の患者はいずれもた だ一部の症状が瀨に類似していただけで㚣り皮温の相異 は当然と考えられる。

以上要約するに自律神経毒に対する健常人の皮温变動 けその薬物の作用のみに帰せらるべき変化を示し, 軽疜: 斑紋瀨も健䐂人に比し反忘度の減弱扣よび時間的経過の 遲延が認められるが，な扣薬物自体の作用による变化が

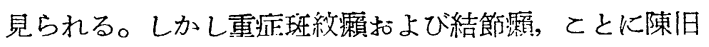
重症例にては皮疹部扎よび皮疹消失部に於てすら，薬物 自体の作用による皮温变化とは考えられない特異の反応 它示す。

すなわち積患者の皮面温か温熱刺战並びに自律神経毒: に対して健序人と全く異つた反忍を示すのは自律神経末 梢部の障但の為でめり，これか瀨患者体温調節部機能失 調の一原因をなするのと思われる。劣此の未悄部の障㥂 は永続性であつて，発疹の殆んど吸収消失して外見上治 㾙したと考えられる部位に於ても尚且特異の皮面温を示 し, 発病早期の治癒により何ら組織学的にも癩病変なら びに皮首萎縮等の变化の認められない完全治瘾したもの でなければ，再び健䐂人の如き皮温動摇は示さないと考 宇らる。

\section{結論}

1. 自律神経毒を男 $1.0 \mathrm{cc}$, 女 $0.7 \mathrm{cc}$ 注射し, その後 1 時間半にわたり前額部扣よび皮疹部の皮温变化並びに 自律神経機能検査を行ない，健常人と比較すると両者間 に著明な相異が見られた。

2.これ等の相異は斑紋䫐より結節䫐に, 軽症例より 重症陳旧例になるにつれ顕著となり，重症例に於ては皮 温変動と自律神経機能との平行関係は全く見ら孔なかつ た。

3. この相異は知覚神経末梢部の障倡の為でせり, 永 続性で発疹の殆んど吸収消失し，外見上治瘾したと考え られる部位に於ても少認められる。

4. 知覚障碍を有し鑑別困難な非獺患者と㸊との鑑別 は皮温測定に低つても或る程度可能であると考えられ る。（本論文は科学研究費に負ら処大でむる。）

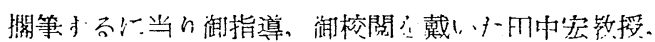
是立修塔助繁授に深謝す。

\section{文要神}

1) Masakazu Haschimoto: Fieberstudien. II Mitteilung : Über den Einfluss unmittelbaren Erwärmung und Abkühlung des Wärmezentrums auf die TemperaturWirkugen von verschiedenen Pyrogenen und antipyretischen Substanzen. Arch. f. exp. Palhol. u. Parmak. 78 394 (1915)

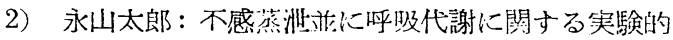
研究 (第 2 報) 23 神経毒の影響似就て 阊山医学会雑沇: 44. 2132 (昭和 7)

3）田坂定孝：体温の研栄（第 2 回報告）自律神経毒 及内分必製㓝が人体温に久ぼす影響に就て 東宗医学会 雑誌 4587 (昭和 6 )

4) 橋本 正：諸種自律神経毒並びに内分必製剂の生 体温度に及ぼす影響 新潟医会誌 64299 (昭和25)

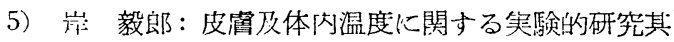

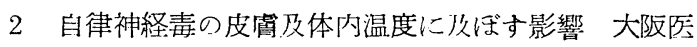
学会雑誌 $37 \quad 1161$ (昭和13)

6) H. Eppinger, W. Foltea u. c. Rudinger: Ueber die Wechselwirkung der Drüsen Zeitsehr. f. Klin. Med. $66 \quad 1$ (1908)

7) A. J. Juschtescheko: Der Einflu $\beta$ des Thyreoidins, Spermins und Adrenalins sowie der Entfernung der Schilddrüse und der Testikeln auf die Oxydationsprozesse, den Atmungsgasaustausch und die Giftigkeit des Harns bei Tieren. Biochemische Zeitsrhrift 15 365 (1909)

8) H. Freund und E. Grafe : Stoffwechseluntersuchungen beim experimentellen Kochsalzfieber. Arch. f. experim. Pathol. u. Pharmakol. 6755 (1912)

9）佐伯利吉：副腎剔出並びにアドレナリン注射に依 る体温動摇に就て 医事公論 1182 号（昭和10)

10) O. Riesser: Über Tonus und Kreatingehalt der Muskeln in ihren Beziehungen zu Wärmeregulation und Zentral-sympathischer Erregung. Arch. f. experim. Pathol. u. Pharmakol. 80183 (1917)

11) G. Oliver-E. A. Schäfer: On the Physiological action of extracts of Pituitary body and certain other glandular Organ. J. of Physiology $18 \quad 27.7$ (1895)

12) J. Bauer: Zur Funktionsprüfung des vegetativen Nervensystems. Deutsch Archiv f. Klin. Med. 10739 
(191')

13）灯出次郎：体温調節中罒のロカリザチオンに就て 生理学研究 12438 (昭和10)

14）川島英一：大体温に灭ぼす影響 奏験楽物学雑誌 9107 (昭和11)

15）土田正義：アドレナリンによる犬体温変化に関す る研究 其ノ 1 アドレナリンの家東体温に及ぼす影響 実験薬物学雑誌 $20 \quad 65$ (昭和18)

16）黑沢 豊：副交感神経毒の体温下降作用機犆に就

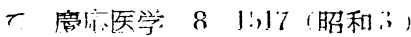

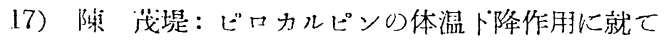
実験薬物学雑誌 8367 (昭和10)

18）吉永阙：動物体温に関する実験的研究 福朔原 科大学雑誌 1842 (大IE14)

19）町田晶直：アドレナリンの南管作用知見禣遺 特 に諸血管领域に於ける流血状態の相互関係心就て 京都 府立医科大学雑誌 52057 (昭和 6) 